[Research Paper]

반응열과 탄화도가 열방출율에 미치는 영향에 관한 연구

\author{
이명규・박설현 ${ }^{*}$ \\ 조선대학교 기계시스템 - 미래자동차공학과 대학원생, *조선대학교 기계공학과 교수
}

\title{
Effect of Heat of Reaction and Charring Properties on Heat Release Rate during Combustion
}

\author{
Myung-Kyu Lee $\cdot$ Seul-Hyun Park ${ }^{* \dagger}$ \\ Graduate Student, Dept. of Mechanical System and Automotive Engineering, Chosun Univ., \\ *Professor, Mechanical Engineering, Chosun Univ.
}

(Received October 11, 2021; Revised November 4, 2021; Accepted November 8, 2021)

\section{요 약}

화재 발생 시 열방출율은 가연물의 열분해율과 유효 연소열의 상관관계에 의해서 결정된다. 가연물의 열분해율을 정확하게 결정하기 위해서는 반응열(heat of reaction)에 대한 이해가 중요하다. 하지만 목재와 같이 연소과정에서 탄 화가 발생되는 경우 다단계 열분해 반응을 거치기 때문에 반응열을 정확하기 측정하기 어렵다. 본 연구에서는 가연 물의 반응열 차이와 탄화도의 비율이 연소 시 발생하는 열방출율에 어떠한 영향을 미치는지 알아보기 위해 ISO 5660-1 콘칼로리미터 실험을 수행하여 열방출율 측정하였고 fire dynamics simulator (FDS) 전산 해석을 통해 계산된 값과 비교·분석하였다. 가연물로는 수분을 제거한 소나무과 상록수인 douglas-fir를 사용하였다. 콘칼로리미터 실험과 $\mathrm{FDS}$ 전산해석 결과를 바탕으로 반응열과 탄화도의 증가가 열방출율 감소와 직접적인 상관관계가 있음을 확인하였다.

\begin{abstract}
The heat release rate (HRR) of fires can be determined from the relationship between the thermal pyrolysis rate of combustibles and the effective heat of combustion. To accurately determine the thermal pyrolysis rate of combustibles, it is important to understand the heat of reaction of combustibles. However, this parameter is difficult to measure for combustibles, such as wood, that produce charring during combustion because they undergo a multi-step pyrolysis reaction. In this study, the ISO 5660-1 standard method was used to perform cone calorimetry experiments to understand how the HRR is affected by the heat of reaction heat and charring properties of combustibles. To this end, the HRR calculated using FDS computational analysis was compared to the measured value from the ISO 5660-1 cone calorimetry experiments. A dehydrated Douglas-fir, an evergreen tree of the pine family, was used as a combustible material. The cone calorimetry experiment and FDS computational analysis results confirmed that increases in the heat of reaction and charring properties were directly correlated with the decrease in the HRR.
\end{abstract}

Keywords : ISO 5660-1 cone calorimeter, Charring, Douglas-fir, Heat of reaction, Heat release rate

\section{1. 서 론}

목재는 자연 친화적이며 심미성이 뛰어난 재료이다. 또 한, 다양한 형태로 가공이 가능하여 단열성과 내구성이 뛰 어난 기계적 성질을 가지고 있다. 최근 전통 가옥 스타일의 주택과 목재 문화재의 개보수와 관련해 목재의 사용이 증 가하는 추세이다. 또한, 국내의 신축 공동 주택의 $90 \%$ 이
상에 목재 및 목질 재료가 내장재로 사용되고 있으며(1) '국 가 법령집의 2013년 발효된 목재의 지속가능한 이용에 관 한 법률'을 기반으로 친환경 재료인 목재의 사용이 더욱 증가하고 있다(2). 그러나 목재가 많이 적용된 건축물 일수 록 우려가 되는 것은 화재에 의한 안전 문제일 것이다. 소 방청의 2020년 화재통계연감 자료에 의하면 건축·구조물 화재가 24,629 건으로 전체 화재의 $64.5 \%$ 를 차지하고 있으

† Corresponding Author, TEL: +82-62-230-7174, FAX: +82-62-230-7171, E-Mail: isaac@chosun.ac.kr

(c) 2021 Korean Institute of Fire Science \& Engineering. All right reserved. 
며, 사망자 300명(82.2\%), 부상자 1,583명(82.6\%), 5,328억 원(88.7\%)의 재산 피해를 발생시킴으로써 유형별 화재 중 매년 가장 큰 인명, 재산 피해 규모를 차지하고 있다 ${ }^{(3)}$. 최 근 건축물에 대한 화재 안전성에 대한 공학적 연구(4)가 활 발히 진행되고 있지만, 건축 내장재로 관심이 주목되는 있 는 목재 가연물의 연소 특성과 화재의 성장에 관한 기초 연구는 부족한 실정이다.

화재 통계에서 알 수 있듯이 화재로 인한 인적·물적 피 해가 증가하는 문제를 해결하기 위해서는 건축내장재의 대 다수를 차지하고 있는 고체 가연물의 열방출율이 정확하게 예측이 되어야 하고 이를 활용해 화재 성장 및 확산에 대 한 이해를 기반으로 한 연구가 이루어야 한다. 특히, 건축 물 특정 공간의 화재 열방출율에 대한 실험과 전산 해석에 있어 중요한 요소 중 하나는 목재 가연물의 특성에 대한 이해이다. 목재 가연물의 특성은 poly methyl methacrylate (PMMA)와 같은 합성수지 가연물과 달리 연소 시 흔히 숯 이라고 말하는 탄화가 생성되고, 계절, 장소, 기후, 가공 및 건조상태에 따라 각기 다른 수분 함량을 가지는 특징이 있 다. 목재 가연물에 열이 가해지면 가연성 증기와 탄화로 열 분해되며 공기와 적절하게 혼합되어 일정 온도 조건을 만 족시켜 연소반응으로 이어지고 화염으로부터 가연물의 표 면에 전달되는 열유속에 의해 내부 온도가 상승함으로써 열분해를 촉진시킨다(5).

Hong 등()은 목재 가연물의 연소 시 생성되는 탄화가 열 방출에 미치는 영향을 콘칼로리미터 실험과 전산 해석을 통해 목재의 탄화층이 가연물에 열 장벽(thermal barrier)을 형성해 내부로 열전도를 방해하여 열분해율을 감소시키는 것을 보고하였다. Mikkola ${ }^{(7)}$ 는 콘칼로리미터 실험을 통해 수분 및 외부 열유속의 함수로 탄화율을 측정하였고 이를 통해 목재의 수분 함량이 탄화율에 영향을 미친다는 것을 보고하였다. 이러한 목재 수분 함량의 증가는 열분해를 통해 가연성 증기를 발생시킬 때 필요한 반응열(heat of reaction) 을 증가시키고 궁극적으로는 열방출율에 영향을 줄 수 있다 는 것을 의미한다. 또한, 다른 선형연구에 따르면 건조된 목 재를 기준으로 Mell 등(8)은 2,259 kJ/kg, Costa와 Sandberg ${ }^{(9)}$ 는 $100-300 \mathrm{~kJ} / \mathrm{kg}, \mathrm{Paker}^{(10)}$ 는 $2,400 \mathrm{~kJ} / \mathrm{kg}$ 의 반응열을 해석에 적 용하는 등 문헌에서 보고된 값에 상당한 차이가 있는 것을 확인할 수 있다.

본 연구에서는 목재의 수분 함량에 따라 달라질 수 있는 반응열의 변화가 열방출율에 어떠한 영향을 미치는지 콘칼 리미터 실험과 전산 해석의 비교를 통해 알아보았다. 아울 러 목재의 열분해율에 영향을 줄 수 있는 탄화도의 영향도 살펴보았다. 실제 목재의 연소 실험을 반복 수행하여 각 변 수별(반응열, 탄화도)로 열방출율의 영향을 정량적으로 분 석하기 힘든 한계로 인해 미국 국립 표준기술원(National Institute of Standards and Technology, NIST)에서 개발한 오 픈 소스 화재 시뮬레이션 코드인 FDS 6.7.1 (fire dynamics simulator)를 이용하여 전산 해석을 수행하였다. 또한, 전산
해석의 검증을 위해 ISO 5660-1 콘칼로리미터 실험을 통해 열 방출율을 측정하였고, 시차주사열량법(differntial scanning calorimetery, DSC), 열중량분석법(thermogravimetric analysis, $\mathrm{TGA}$ )을 활용하여 전산 해석에 필요한 열물성, 열분해 물성 을 도출하였다. 이후 입력된 탄화도와 반응열의 변수가 열 방출율에 어떠한 영향을 미치고 실험 결과와 어떠한 차이 를 보이는지 비교하였다. 추가적으로 전산 해석 시 격자 수 에 따라 열방출율의 민감도를 분석하였고, 연구에서 사용 된 목재 가연물은 건축·토목, 가구재에 널리 사용되는 소나 무과에 속하는 상록수인 douglas-fir를 선정하였다.

\section{2. 실험 및 전산 해석 방법}

\section{1 콘칼로리미터 및 douglas-fir 열물성 측정 실험}

본 연구에서는 douglas-fir 가연물의 연소과정에서 방출되 는 열방출율을 측정하기 위해 ISO 5660-1 콘칼로리미터를 사용하였다. ISO 5660-1 콘칼로리미터는 수평 방향의 콘 히 터 복사열이 균일하게 시편에 전달되어 연소 생성물의 산소 농도와 산소 소모량을 측정하여 열방출율을 결정해 화재 특 성을 측정하는데 널리 사용되고 있다 ${ }^{(1)}$. Douglas-fir의 열방 출율 측정 실험을 수행하기 전 가연물 시편 $(100(\mathrm{~W}) \times 100$ (L) $\times 29(\mathrm{~T}) \mathrm{mm}$ )의 함수율 변화에 의한 영향을 최소화하 기 위해 ASTM D4442-92 기준(12)을 참고하여 $104{ }^{\circ} \mathrm{C}$ 에서 시편의 질량변화가 없을 때까지 건조를 수행하였다. 연소 실험 전 콘 히터에서 수직 방향으로 시편 표면에 도달하는 복사열 유속은 $50 \mathrm{~kW} / \mathrm{m}^{2}$ 로 일정하게 유지되도록 복사 열 유속계를 이용하여 보정하였다. 시편과 콘 히터 사이의 간 격은 $25 \mathrm{~mm}$ 이고 적용된 환기 유량은 $24 \mathrm{~L} / \mathrm{s}$ 이다. 콘 히터 로부터 시편 표면에 도달하는 $50 \mathrm{~kW} / \mathrm{m}^{2}$ 의 복사열에 의해 자연 점화가 이루어지고 시험의 종료는 화염의 소멸과 시 편의 질량 변화가 없는지를 관찰하여 결정하였다.

FDS 전산해석을 통해 고체 가연물의 열방출율을 계산하 기 위해서는 시편의 질량과 부피를 측정하여 바로 계산이 가능한 밀도 이외에도 비열과 열전도계수 등과 같은 열물 성치가 필요하다. 본 연구에서는 시차주사열량법(differntial scanning calorimetery, DSC)을 활용하여 douglas-fir의 비열 을 측정하였다. DSC는 측정 전에 인듐(indium)을 사용하여 열량과 온도를 보정하였고, 질소 환경에서 $20{ }^{\circ} \mathrm{C} / \mathrm{min}$ 의 승 온 속도로 사파이어 샘플의 열량과 douglas-fir의 열량을 측 정한 후 아래 식(1)을 이용하여 비열을 측정하였다.

$$
C_{p}=\frac{H}{h} \times \frac{m_{\text {reference }}}{m_{\text {sample }}} \times C_{p, \text { Reference }}
$$

여기서 $C_{p}$ 는 douglas-fir의 비열 $C_{p, \text { Reference }}$ 는 사파이어의 비열, $m_{\text {sample }}$ 은 douglas-fir의 질량, $m_{\text {reference }}$ 는 사파이어의 질량, $H$ 는 샘플과 빈 팬사이의 열량 차이, $h$ 는 사파이어와 빈 팬 사이의 열량 차이를 의미한다. Figure 1 은 $\mathrm{DSC}$ 로 측 


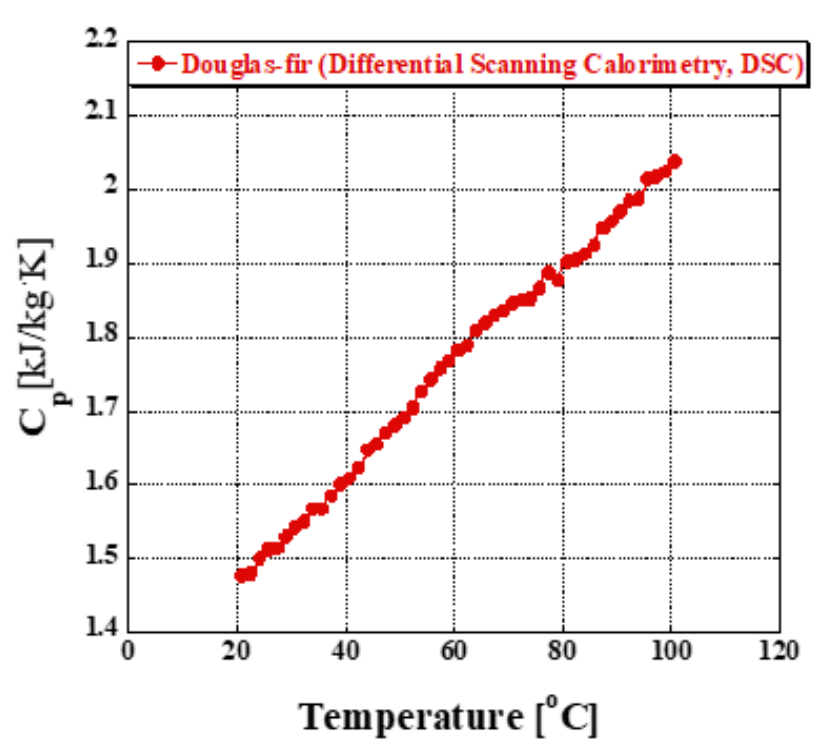

Figure 1. Douglas-fir graph of specific heat according to temperature.

정된 douglas-fir 비열의 그래프이다. 그림에서 볼 수 있는 바와 같이 온도가 상승함에 따라 측정된 비열도 선형적으 로 증가하는 것을 관찰할 수 있다.

고체가연물의 열방출율을 전산해석 기법으로 계산하기 위해 필요한 주요 인자 중 하나인 열전도계수는 섬광법 (light flash method, LFM)을 이용하여 비접촉식으로 측정하 였다. Douglas-fir의 상단면에 고출력의 제논램프의 섬광을 조사하여 흡수된 열량이 하단 면으로 전달될 때 시간에 따 라 온도를 측정하고, 최고 온도에 도달하여 열평형 상태를 이루면 열확산율, $\alpha$ (thermal diffusivity)를 측정하였다. 측정 된 열확산율로부터 아래 식 (2)를 이용하여 열전도계수, $\mathrm{k}$ 를 역산하였다. 이때 $\rho$ 는 douglas-fir 샘플의 밀도이다.

$$
k=\alpha C_{p} \rho
$$

열방출율의 전산 해석을 위해 thermogravimetric analysis (TGA)에서 질량 별 승온율 결과를 통해 kissinger 방법과 flynn \& wall 방법으로 활성화에너지 $E$, 선인자계수 $A$ 를 결 정하였다. kissinger 방법은 분해거동이 1 차 반응식을 따른다 고 가정하고, 데이터 해석에 아래 식 (3)을 사용하였다 ${ }^{(13)}$.

$$
\ln \left(\frac{\beta}{T_{\max }^{2}}\right)=\ln \left(\frac{A \cdot R}{E}\right)-\frac{E}{R \cdot T_{\max }}
$$

여기서 $T_{\max }$ 는 최대 전환이 발생하는 온도 $[K], \beta$ 는 승 온속도 $\left[{ }^{\circ} \mathrm{C} / \mathrm{min}\right], E$ 는 활성화 에너지 $[K J / m o l], A$ 는 preexponential 인자, $R$ 은 기체상수로 $8.314 \mathrm{~J} / \mathrm{mol} \cdot K$ 이다. X축 을 $1 / T_{\max }, \mathrm{y}$ 축을 $\ln \left(\beta / T_{\max }^{2}\right)$ 로 각각 설정하여 그 결과를 Figure 2에 도시 하였고 기울기로부터 $E, \mathrm{y}$ 절편값으로부터 $A$ 값을 결정하였다.

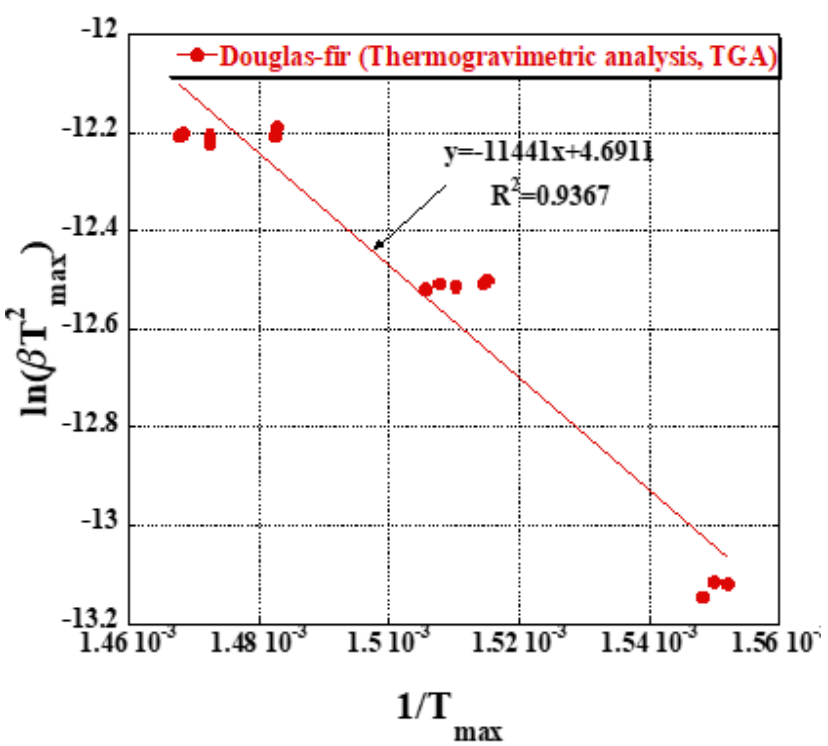

Figure 2. Measured $\ln \left(\beta / T_{\max }^{2}\right)$ plotted as a function of $1 / T_{\max }$.

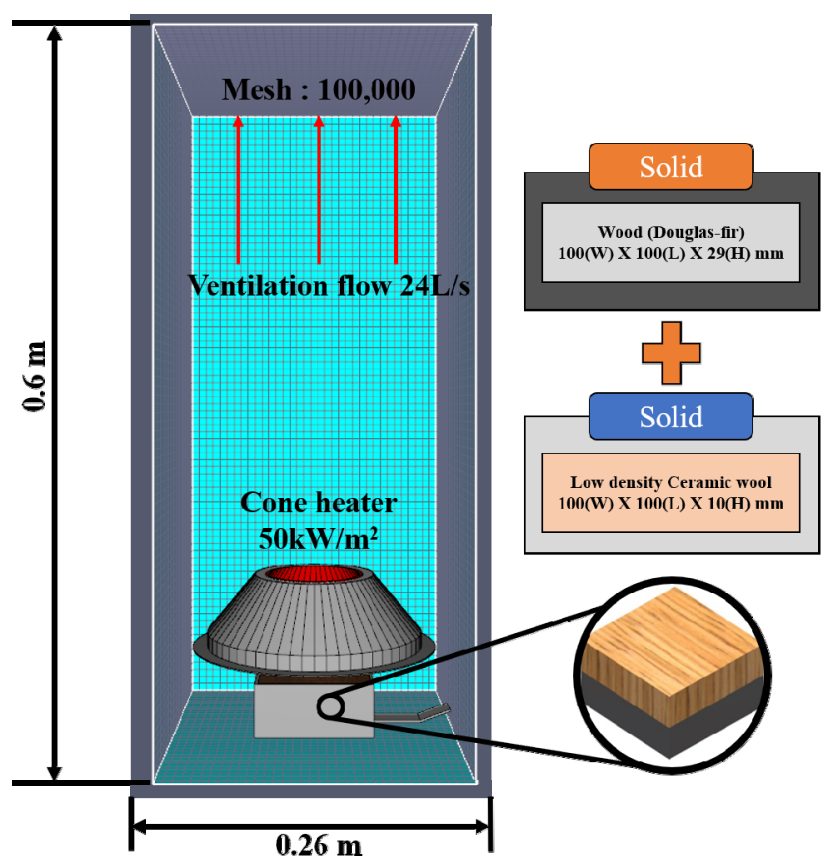

Figure 3. Computational domain and mesh generated for the ISO 5660-1 calorimeter experiment.

\subsection{FDS 열방출율 전산 해석 방법}

FDS 전산 해석은 Figure 3 과 같이 $0.26(\mathrm{~W}) \times 0.26(\mathrm{~L}) \times$ $0.6(\mathrm{H}) \mathrm{m}$ 크기의 해석 공간에서 수행되었으며, Douglas-fir 시편의 하단부는 단열 처리를 하였다. 해석공간 상단부에 는 콘칼로리미터 실험과 동일하게 $24 \mathrm{~L} / \mathrm{s}$ 의 유량을 입력하 였다. 콘히터는 ISO 5660-1 규격에 맞게 모델링하였고 콘 히터와 가연물인 douglas-fir 표면 사이의 거리는 $25 \mathrm{~mm}$ 로 설정하였다. FDS 콘칼리미터 전산 해석을 수행 시 적용한 격자 수는 50,000 에서 최대 320,000 개로 격자 수를 늘려가 
Table 1. Summary of Thermal and Decomposition Properties of Douglas-fir \& Char

\begin{tabular}{|c|c|c|c|c|c|c|c|}
\hline Parameter & Unit & \multicolumn{2}{|c|}{ Typical value } & Parameter & Unit & \multicolumn{2}{|c|}{ Typical value } \\
\hline \multicolumn{4}{|c|}{ Douglas-fir Thermal Properties } & \multicolumn{4}{|c|}{ Douglas-fir decomposition properties } \\
\hline Density & $\mathrm{kg} / \mathrm{m}^{3}$ & \multicolumn{2}{|c|}{474.78} & Activation energy, E & $\mathrm{kJ} / \mathrm{kmol}$ & \multicolumn{2}{|c|}{$9.51 \times 10^{4}$} \\
\hline \multirow{5}{*}{ Thermal conductivity, $\mathrm{k}$} & \multirow{5}{*}{$\mathrm{W} /\left(\mathrm{m} \cdot{ }^{\circ} \mathrm{C}\right)$} & Temp. & Value & Pre-exponential, A & $1 / \mathrm{s}$ & 1.2 & $10^{6}$ \\
\hline & & $10{ }^{\circ} \mathrm{C}$ & 0.097 & Heat of reaction & $\mathrm{kJ} / \mathrm{kg}$ & & \\
\hline & & $27^{\circ} \mathrm{C}$ & 0.100 & \multicolumn{4}{|c|}{ Char thermal properties } \\
\hline & & $42{ }^{\circ} \mathrm{C}$ & 0.103 & Charring ratio & $\%$ & \multicolumn{2}{|c|}{18} \\
\hline & & $62{ }^{\circ} \mathrm{C}$ & 0.109 & Density, $\rho$ & $\mathrm{kg} / \mathrm{m}^{3}$ & \multicolumn{2}{|c|}{300} \\
\hline \multirow{5}{*}{ Specific heat, $c_{p}$} & \multirow{5}{*}{$\mathrm{kJ} /\left(\mathrm{kg} \cdot{ }^{\circ} \mathrm{C}\right)$} & Temp. & Value & Thermal conductivity, $\mathrm{k}$ & $\mathrm{W} /(\mathrm{m} \cdot \mathrm{K})$ & \multicolumn{2}{|c|}{0.052} \\
\hline & & $25{ }^{\circ} \mathrm{C}$ & 1.501 & \multirow{4}{*}{ Specific heat, $c_{p}$} & \multirow{4}{*}{$\mathrm{kJ} /(\mathrm{kg} \cdot \mathrm{K})$} & Temp. & Value \\
\hline & & $50{ }^{\circ} \mathrm{C}$ & 1.693 & & & $27{ }^{\circ} \mathrm{C}$ & 0.71 \\
\hline & & $75{ }^{\circ} \mathrm{C}$ & 1.866 & & & & \\
\hline & & $100{ }^{\circ} \mathrm{C}$ & 2.029 & & & $1724 \mathrm{C}$ & 2.04 \\
\hline
\end{tabular}

면서 계산된 열방출율과 콘칼리미터에서 측정된 열방출율 각각 비교하였고 이러한 연소 과정의 모사는 열분해 과정 을 하나의 단순 과정으로 정의하는 단순 반응 모델을 적용 하였다. 단순 반응모델은 한 단계의 과정에 의해 생성물인 가스, 타르, 숯으로 반응하는 모델로서 타르나 탄화에 의한 2차 연소반응을 표현하지 못하는 기술적인 한계가 있다. 하지만 계산이 단순화되어 입력된 변수가 열방출율에 어떠 한 영향을 미치는지 알아보는데 효과적이기 때문에 본 연 구에 적용하였다.

Douglas-fir의 열분해 시 생성되는 가연성 증기(연료)가 공기와 반응하여 생성되는 부산물은 그룹화된 화학종을 이 용하여 식 (4)와 같이 나타낼 수 있다(14).

$$
\begin{aligned}
& C_{1} H_{1.7} O_{0.74} N_{0.002}+1.034799\left(O_{2}+3.76 N_{2}\right) \stackrel{\text { yields }}{\rightarrow} \\
& 1\left(0.978093 \mathrm{CO}_{2}+0.849027 \mathrm{H}_{2} \mathrm{O}+0.004386 \mathrm{CO}\right. \\
& \left.\quad+0.019469 \text { Soot }_{\mathrm{C} 0.9 \mathrm{H} 0.1}+3.891843 \mathrm{~N}_{2}\right)
\end{aligned}
$$

열분해 과정을 통해 줄어드는 고체 가연물의 단위 면적 당 질량 감소율이 가연성 증기의 생성율과 동일하다고 가 정하면 단위 면적당 열방출율(heat release rate per area, HRRPUA), $\dot{q}^{\prime \prime}$ 는 단위 면적 당 가연성 증기의 생성율, $\dot{m}^{\prime \prime}$ 과 유효 연소열(effective heat of combustion, $\Delta H_{e}$ )의 상관관계 를 이용하여 식 (5)를 통해 계산할 수 있다.

$$
\dot{q}^{\prime \prime}=\dot{m}^{\prime \prime} \Delta H_{e}=\Delta H_{e} \rho_{0} \int_{0}^{L} \sum_{i}\left(1-\nu_{s, i}\right) A_{i}\left(\frac{\rho_{i}}{\rho_{0}}\right)^{n_{i}} \exp \left(\frac{-E_{i}}{R T(x)}\right) d x
$$

이때 식 (5)에서 $E$ 는 활성화 에너지(activation energy), $A$ 는 선인자 계수(pre-exponential factor), $\nu_{s, i}$ 는 목재 가연물 탄화도, $R$ 은 기체상수, $T$ 는 샘플 표면 온도, $n_{i}$ 는 질량 분 율을 각각 의미한다. 목재 가연물 탄화도는 콘칼로리미터

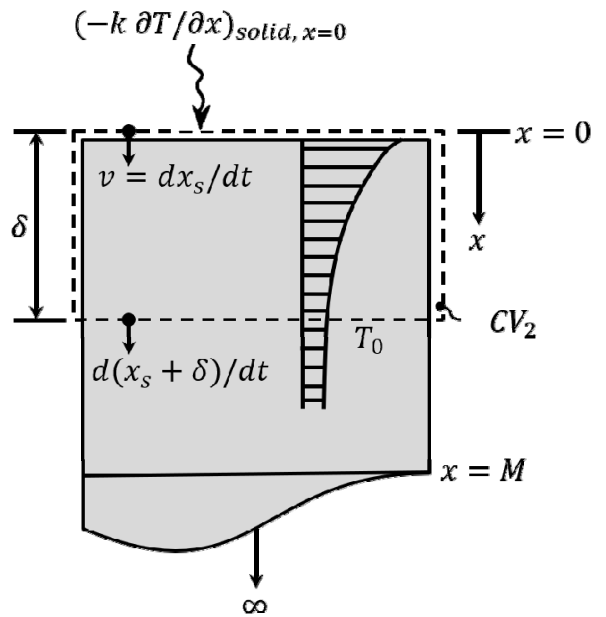

Figure 4. Boundary conditions for combustion of solid combustibles.

연소 실험 전의 douglas-fir 질량 $\left(w_{1}\right)$ 과 연소 후의 질량 $\left(w_{2}\right)$ 을 측정하고 식 (6)을 이용하여 생성되는 탄화도를 $18 \%$ 로 결정하였다 ${ }^{(15)}$.

$$
\text { Charring ratio }=w_{2} / w_{1} \times 100 \%
$$

FDS 열방출율 전산 해석을 수행하기 위해 본 연구에서 사용된 douglas-fir의 기준 열물성 값은 앞서 기술된 바와 같이 $\mathrm{DSC}, \mathrm{TGA}, \mathrm{LFM}$ 기법 등을 통해 측정하였고 Table 1 에 정리하였다.

Douglas-fir 가연물의 내부 온도는 식 (7)을 이용해서 예 측할 수 있고 Figure 4에서 볼 수 있듯이 깊이 방향 $(x)$ 의 1 차원 열전도 방정식을 통해 계산할 수 있다.

$$
\rho_{s} c_{p, s} \frac{\partial T_{s}}{\partial t}=\frac{\partial}{\partial x}\left(k_{s} \frac{\partial T_{s}}{\partial x}\right)+\dot{q}^{\prime \prime \prime}{ }_{s, r}+\dot{q}^{\prime \prime \prime}{ }_{s, c}
$$




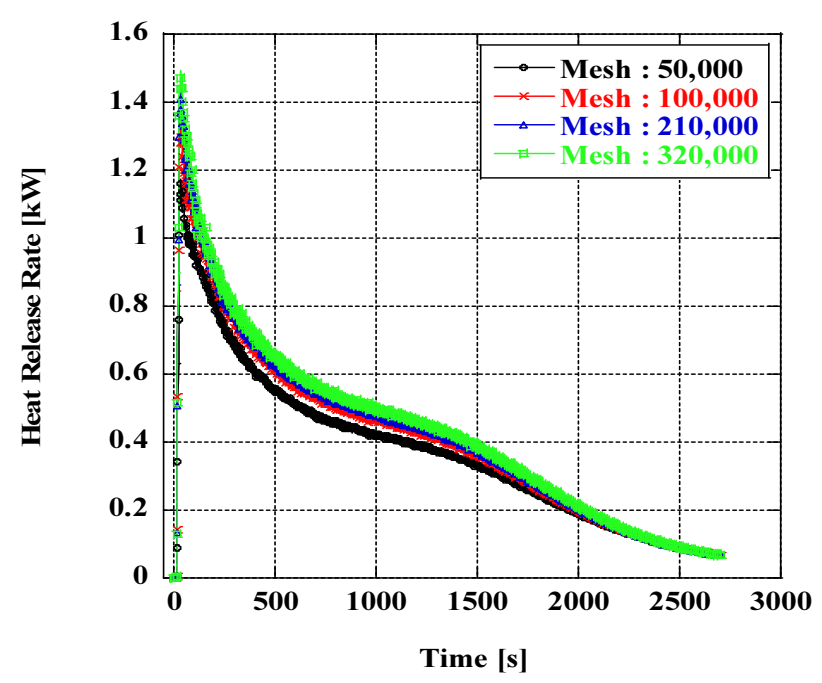

Figure 5. Calculated heat release rate of Douglas-fir specimen as a function of time with the different number of meshes.

식(7)에서 $T_{s}$ 는 가연물의 온도, $t$ 는 시간, $\rho_{s}$ 은 가연물의 밀도, $c_{p, s}$ 는 가연물의 비열, $k_{s}$ 는 가연물의 열전도계수, $\dot{q}^{\prime \prime \prime}{ }_{s, r}$ 와 $\dot{q}^{\prime \prime \prime}{ }_{s, c}$ 은 생성 항을 의미하며 가연물 표면 $(x=0)$ 과 바닥 면 $(x=M)$ 에 적용된 경계 조건은 각각 식 (8)와 (9)와 같다.

$$
\begin{aligned}
& -k \frac{\partial T}{\partial x}(0, t)=\dot{q}_{\text {conv }}^{\prime \prime}+\dot{q}_{\text {rad }}^{\prime \prime}-\dot{m}^{\prime \prime} \triangle H_{v} \\
& -k \frac{\partial T}{\partial x}(M, t)=0
\end{aligned}
$$

식 (8)에서 $\dot{q}^{\prime \prime}{ }_{r a d}$ 와 $\dot{q}^{\prime \prime}{ }_{c o n v}$ 는 각각 가연물 표면에서 복사와 대류에 의해서 발생되는 열전달율이고, $\dot{m}^{\prime \prime} \Delta H_{v}$ 는 가연성 중기생성에 필요한 반응과 관련된 열전달율을 의미한다.

\section{3. 실험-전산 해석 결과 및 고찰}

Figure 5는 FDS 전산 해석을 통해서 계산된 douglas-fir 가연물의 열방출율을 시간의 함수로 도시한 결과이다. 콘 히터로부터 전달된 복사열에 의해 douglas-fir의 열분해가 촉진되어 자연점화가 일어난 직후 연소반응과 함께 급격한 열방출이 이루어지는 것을 확인할 수 있다. 이때 열방출율 예측을 위해 FDS 전산해석에 사용된 douglas-fir와 탄화의 물성치는 Table 1에 정리되어 있다. 그림에서 관찰할 수 있 듯이 해석공간 내 격자 수가 가장 적은 50,000 개의 경우 계 산된 열방출율이 100,000 개인 경우 비해 다소 작게 예측되 었지만 격자수가 100,000 개 이상으로 증가하면 계산된 열 방출율에는 큰 변화가 없는 것을 확인하였다. 이 결과를 바 탕으로 본 연구에서는 해석 공간 내 100,000 개의 격자가 존 재하는 경우와 Table 1 에 제시된 douglas-fir와 탄화의 물성 치 기준으로 전산 해석을 수행하였고 반응열과 탄화도의 변화가 열방출율에 미치는 영향을 살펴보았다.

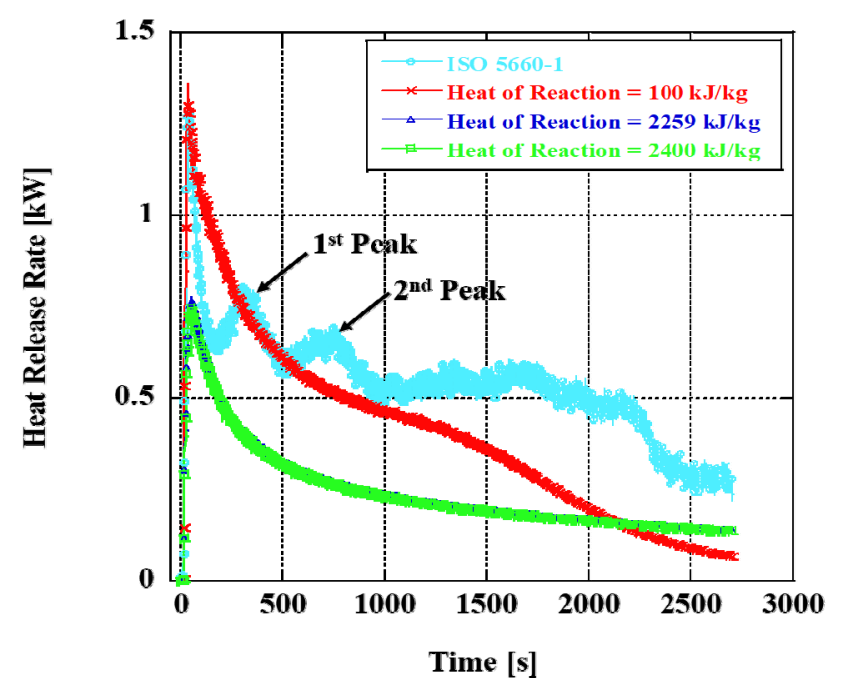

Figure 6. Comparisons of the HRR measured from the cone calorimetery experiment and calculated with different heat of reactions.

Figure 6은 콘칼로리미터 연소실험을 통해 측정된 열방출 율 결과와 앞서 언급한 선행연구자 ${ }^{(8-10)}$ 들이 제시한 douglas-fir 목재의 반응열을 FDS에 입력하여 계산된 열방출율을 비교 한 그래프이다. 그림에서 볼 수 있듯이 콘칼로리미터 연소 실험에서 측정된 최대 열방출율은 약 $1.3 \mathrm{~kW}$ 로 Table 1 에 제시된 물성값을 입력하여 계산한 최대 열방출율과 유사한 것을 확인할 수 있다. 콘칼로리미터 연소실험에 측정된 열 방출율과 Table 1의 물성치를 이용하여 계산된 열방출율은 모두 연소반응 이후 급격히 증가하여 최대 값에 도달한 뒤 줄어드는 경향을 보이고 이는 열적으로 두꺼운 가연물의 전형적인 열방출율 변화 양상이다.

Schartel과 Hull ${ }^{(1)}$ 은 열적으로 두꺼운 목재와 같은 탄화 가연물은 탄화층의 균열이나, 타르의 2 차 반응에 따라 열 분해가 촉진되어 $\mathrm{n}$ 차 열방출율 피크가 발생할 수 있다고 보고하였다. 실제 콘칼로리미터 연소실험에서는 이러한 $\mathrm{n}$ 차 피크가 발생하였으나 FDS 전산해석으로 계산된 열방출 율 특성은 이러한 특징을 표현하지 못하는 기술적인 한계 를 분명히 보여주고 있다.

아울러 콘칼로리미터 연소실험을 통해 측정된 열방출율 은 점화 후 $1000 \mathrm{~s}$ 이후에도 약 $0.5 \mathrm{~kW}$ 를 $2,000 \mathrm{~s}$ 까지도 유지 하는 반면 FDS 전산해석을 통해 계산된 열방출율은 지속적 으로 감소하는 것을 관찰할 수 있다. 이는 실제 목재의 연소 반응 시 발생하는 탄화가 훈소 반응(smoldering reaction)을 발생시켜 비교적 느린 열분해 과정을 지속시키지만 FDS 전산해석에 적용된 열분해 모델의 경우 탄화도의 비율만을 정량적으로 고려할 뿐 훈소반응을 고려하지 못하기 때문으 로 판단된다.

Figure 6에는 Table 1에 제시된 물성치(반응열 $100 \mathrm{~kJ} / \mathrm{kg}$ 기준)를 입력하여 계산된 열방출율과 douglas-fir 목재의 반 응열로 보고된 $2,259 \mathrm{~kJ} / \mathrm{kg}, 2,400 \mathrm{~kJ} / \mathrm{kg}$ 를 각각 입력하여 계 


$$
\begin{aligned}
& \operatorname{wood} \stackrel{\text { heat }}{\longrightarrow} \text { char }+ \text { tar }+ \text { gas } \\
& \operatorname{tar} \stackrel{\text { char }}{\longrightarrow} \text { char }+ \text { gas }+ \text { heat }
\end{aligned}
$$

Figure 7. Schematics of biomass pyrolysis process ${ }^{(17)}$.

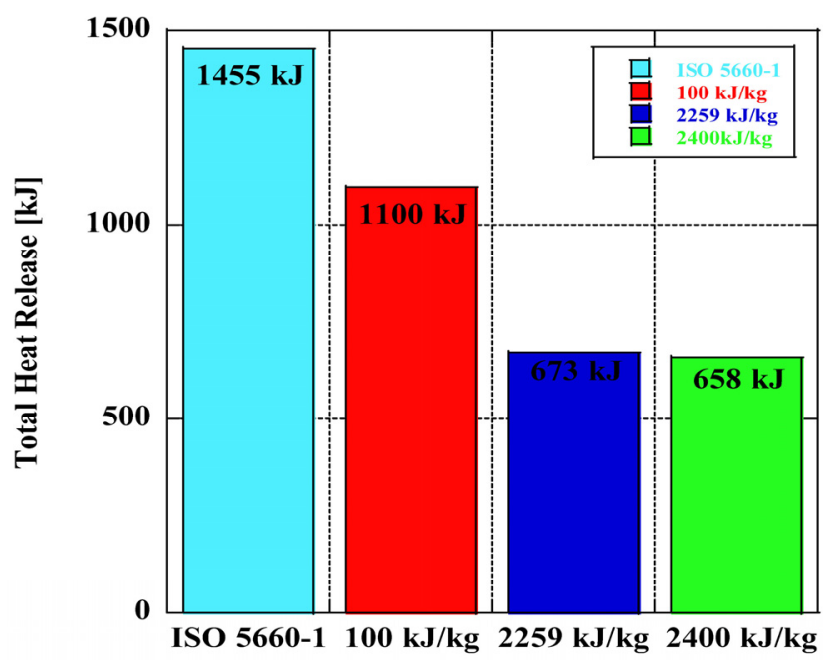

Figure 8. Comparisons of the THR varying with different heat of reactions.

산된 열방출율을 비교한 결과이다. FDS 전산해석 시 입력 된 반응열이 크게 증가함에 따라 최대 열방출율이 $1.36 \mathrm{~kW}$ 에서 각각 $0.69 \mathrm{~kW}, 0.66 \mathrm{~kW}$ 로 감소하였다. 또한 반응열이 증가함에 따라 동일한 탄화도 $(18 \%)$ 조건에도 열분해가 급격 히 감소하여 줄어들어 뚜렷한 열방출율 감소세를 보였다.

목재의 경우 열분해 과정은 Figure 7에 도식화를 통해 정 리되어 있는 바와 같이 흡열과 발열 반응으로 구성된 탄화타르 다단계 반응으로 열출입이 복잡하고 계절, 장소, 기 후, 가공 및 건조상태에 따라 각기 다른 수분 함량으로 인 해 반응열을 정량화하기 힘든 것으로 알려져 있다. 또한, 목재의 수분 함량뿐만 아니라 분해 반응 시 주위의 온도나 목재 결의 방향(grain orientation) 등도 탄화도에 영향을 주 어이로 인한 반응열이 영향을 받을 수 있는 것으로 보고된 바 있다 ${ }^{(17)}$.

Figure 8은 Figure 6에 제시된 결과로부터 2,700 s까지 방 출된 열량을 누적시켜 계산한 총 열방출(total heat release, THR)을 도시한 그래프이다. 그림에서 불 수 있는 바와 같 이 FDS 전산 해석 시 선행연구(8-10)에서 제시한 반응열 값 을 입력하여 계산한 총열방출은 크게 차이가 나타나는 것 을 확인할 수 있다. 콘칼로리미터 실험에서 계산된 총 열방 출율이 $1,455 \mathrm{~kJ}$ 로 가장 크고 전산 해석 시 입력된 반응열 이 $100 \mathrm{~kJ} / \mathrm{kg}$ 에서 $2,400 \mathrm{~kJ} / \mathrm{kg}$ 로 증가함에 따라 총 열방출율 은 $1,100 \mathrm{~kJ}$ 에서 $658 \mathrm{~kJ}$ 로 감소하였다. 콘칼로리미터 실험 값과 비교시 훈소에 의한 열분해과정을 무시할 수 있다면
Costa와 Sandberg(9)의 $100 \mathrm{~kJ} / \mathrm{kg}$ 을 반응열로 적용하여 계산 한 경우 실험 결과와 비교적 잘 일치하였다.

앞서 기술한 바와 같이 목재 가연물 화재의 중요 변수인 탄화도는 반응열과 열분해율에 영향을 미칠 수 있고 열방 출율에도 직접으로 영향을 줄 수 있다. 따라서 본 연구에서 는 FDS 전산 해석 시 탄화의 비율을 Table 1 에 제시된 탄 화도 $18 \%(0.18)$ 을 기준으로 전산 해석을 하였고 탄화도 $10 \%(0.1), 28 \%(0.28)$ 를 추가 해석하여 탄화도의 비율이 열 방출율에 어떠한 영향을 미치는지 알아보았다. Figure 9에 는 Table 1에 제시된 탄화도(18\%)를 입력하여 계산된 열방 출율을 기준으로 탄화도 $10 \%(0.1), 28 \%(0.28)$ 를 추가 해석 하여 계산된 열방출율을 도시하였다. 그림에서 볼 수 있는 바와 같이 동일한 반응열 $(100 \mathrm{~kJ} / \mathrm{kg})$ 을 입력하여 계산한 경 우에도 탄화도가 증가함에 따라 열방출율은 급격하게 감소 하는 것을 관찰할 수 있다.

Figure 10은 Figure 9에 제시된 결과로부터 $2700 \mathrm{~s}$ 까지 방 출된 열량을 누적시켜 계산한 총 열방출율(total heat release, $\mathrm{THR}$ )을 도시한 그래프이다. 그림에서 알 수 있듯이 탄화 비율의 증감함에 따라 douglas-fir의 총열방출이 감소하는 것을 확인할 수 있다. 이는 탄화층이 가연물 내부로의 열전 달을 방해하는 열장벽을 형성하여 열분해에 영향을 주기 때문으로 판단된다. 즉, 탄화율이 큰 경우(0.28) 가연물 표 면의 탄화층이 열적 두께를 더욱 증가시켜 가연물 내부로 의 열전도를 방해하고 열분해를 억제하여 열방출율이 낮고 이와 반대로 탄화 비율이 적은 경우(0.1) 탄화층에 의한 열 장벽의 효과가 작아 상대적으로 가연물 표면에서 내부로의 열전도가 급격히 증가하여 열분해가 활발히 일어나 더 많 은 열방출이 일어나는 것을 알 수 있었다.

\section{4. 결 론}

ISO 5660-1 규격을 만족하는 콘칼로리미터를 이용하여 열 적 두께가 두껍고 탄화층이 존재하는 목재 가연물인 douglasfir의 열방출율 측정 실험을 진행하였다. 아울러 넓은 범위에 산포되어 있는 douglas-fir 목재의 반응열과 탄화도가 FDS 전 산 해석 시 열방출율에 어떠한 영향을 미치는지 콘칼로리미 터 실험결과와 비교하여 살펴 보았다. 본 연구를 통해 얻어 진 결과를 요약하면 아래와 같다.

1) 적절한 반응열과 탄화도를 입력하여 계산한 경우 FDS 전산해석을 통해서도 탄화 층이 존재하는 목재 가연 물의 열방출율을 적정 범위내에서 예측할 수 있다. 하지만, $\mathrm{FDS}$ 에서 제공하는 열분해 모델은 목재와 같이 가스, 타르, 탄화 등의 다단계 반응을 거쳐 발생되는 열방출율을 예측 하기에는 기술적인 한계가 분명하였다.

2) FDS 전산 해석 시 목재의 상이한 반응열의 입력에 따 라 계산된 열방출율에 상당한 차이를 보였다. 연소반응 이 후 급격히 증가하여 최대값에 도달한 뒤 줄어드는 목재의 열방출율을 특성을 $\mathrm{FDS}$ 전산해석을 통해도 비교적 잘 예 
측할 수 있었다. 하지만, 탄화층의 균열이나, 타르 2차 반응 으로 열분해가 촉진되어 발생되는 $\mathrm{n}$ 차 열방출율 피크를 표 현하지 못하였다.

3) 탄화도 0.18 을 기준으로 증감하여 FDS 전산해석을 수 행한 결과, 탄화도가 가장 큰 경우(0.28) 가연물의 열적 두 께를 더욱 증가시켜 가연물 내부로의 열전도를 방해하고 열분해를 억제하여 열방출율이 줄어들었고, 이와 반대로 탄화도가 가장 작은 경우 $(0.1)$ 열장벽의 효과가 줄어들어 상대적으로 열방출이 늘어나는 것을 확인하였다.

4) 탄화층이 존재하는 고체 가연물의 FDS 전산해석을 수행 시 열방출율 및 열분해율 결과는 탄화 도와 반응열에 따라 상당한 영향을 받을 수 있으므로 정확한 값의 입력이 중요하다.

\section{후 기}

이 논문은 2021년도 항국항공우주연구원(과제번호 : 17111 1560)의 지원에 의하여 연구되었으며, 아울러 2021년도 산업 통상자원부의 재원으로 한국에너지기술평가원(KETEP)의 지 원을 받아 수행한 연구 과제입니다(No. 20215810100040).

\section{References}

1. Y. Park, B. Jun, J. Seo and S. Kim, "The Improvement of Thermal Conductivity of wood-based Panel for Laminated Flooring Used the Exfoliated Graphite for Heating Energy Conservation", Journal of the Society of Living Environmental System Korea, Vol. 18, No. 6, pp. 650-655 (2011).

2. H. J. Seo and D. W. Son, "Combustion Characteristics of Wood for Interior", Proceedings of 2015 Spring Annual Conference, Architecture Institute of Korea, pp. 411-412 (2015).

3. Y. U. Shin, "Fire Statistical Yearbook", NFA 11-1661000000011-10, National Fire Agency (2020).

4. I. H. Yeo, M. O. Yoon, and J. B. Yoon, "Burning Behavior of Heavy Timber Subjected to Standard Fire", Journal of the Architectural Institute of Korea, Vol. 25, No. 2, pp. 123-132 (2009).

5. C. L. Beyler and M. M. Hirschler, "SFPE Handbook of Fire Protection Engineering", NFPA, USA (2002).

6. T. K. Hong, M. H. Ryu, J. W. Lee and S. H. Park, "Effects of Char Produced from Burning Wood Combustibles on Thermal Pyrolysis", Fire Science and Engineering, Vol. 33,
No. 5, pp. 7-12 (2019). https://doi.org/10.7731/KIFSE.2019. 33.5.007.

7. E. Mikkola, "Charring of Wood Based Materials", Proceedings of the third International Symposium, Fire Safety Science, pp. 547-556 (1991). https://doi.org/10.3801/IAFSS.FSS.3-547.

8. W. Mell, A. Maranghides, R. McDermott, and S. L. Manzello, "Numerical simulation and experiments of burning douglas fir trees", Combustion and Flame, Vol. 156, No. 10, pp. 2023-2041 (2009). https://doi.org/10.1016/j.combustflame. 2009.06.015.

9. F. S. Costa and D. Sandberg, "Mathematical model of a smoldering log", Combustion and Flame, Vol. 139, No. 3, pp. 227-238 (2004). https://doi.org/10.1016/j.combustflame. 2004.07.009.

10. W. J. Parker, "Prediction of the Heat Release Rate of Douglas Fir", Proceedings of the Second International Symposium, Fire Safety Science, pp. 337-346 (1989).

11. V. Babrauskas, "Ignition Handbook: Principles and Applications to Fire Safety Engineering, Fire Investigation, Risk Management and Forensic Science", Fire Science Publishers, USA (2003).

12. ASTM D 4442, "Standard Test Methods for Direct Moisture Content Measurement of Wood and wood-Base Materials", American Society for Testing and Materials, USA (2003).

13. W. I. Kim, S. D. Kim, S. B. Lee and I. K. Hong, "Kinetic Characterizationof Thermal Degradation Process for Commercial Rubbers", J. Ind. Eng. Chem., Vol. 6, No. 5, 348-355 (2000).

14. K. McGrattan, R. McDermott, S. Hostikka, J. Floyd, C. Weinschenk and K. Overholt, "Fire Dynamics Simulator User's Guide", NIST NSPUE2, National Institute of Standards and Technology (2013).

15. C. Anand, B. Shotorban, S. Mahalingam, S. McAllister and R. Weise, "Physics-Based Modeling of Live Wildland FuelIgnition Experiments in the FIST Apparatus", Combustion Science and Technology, Vol. 189, No. 9, pp. 1551-1570 (2017). https://doi.org/10.1080/00102202.2017.1308357.

16. B. Schartel and T. H. Hull, "Development of Fire-Rretarded Mmaterials - Interpretation of Cone Ccalorimeter Data", Fire and materials, Vol. 31, pp. 327-354, (2007). https://doi.org/ 10.1002/fam.949.

17. S Sinha, A. Jhalani, M. R. Ravi, and A. Ray, "Modeling of pyrolysis in wood: A review", J. Solar Energy Society of India, Vol. 10, pp. 41-62, (2000). 